\title{
Universal Jurisdiction in Spain: Substantial Change of Model or Implied Repeal?
}

\author{
Concepción EsCOBAR HERNÁNDEZ*
}

\begin{abstract}
Universal jurisdiction has been the subject of significant controversy since its incorporation in the Spanish legal system in 1985, which has been amended on several occasions. The last modification has been effected by Ley Orgánica $\mathrm{I} / 2014$ which presents itself as a continuation of the previous reforms (in particular in 2009). However, it is questionable that this reform is a continuation of previous ones. It is also questionable that it is a mere reform of universal jurisdiction and not a tacit disappearance of this institution in the Spanish system. From a critical perspective, this paper deals with three issues of great importance for the survival of universal jurisdiction in Spain: (i) the new formulation of the principle of subsidiarity and its relationship with the new substantive and procedural requirements introduced by the reform of 20I4; (ii) the relationship between the new model of universal jurisdiction and international law; and (iii) the consequences of the retroactive application of the law and its compatibility with the international and constitutional principles that govern the right to effective judicial protection.
\end{abstract}

Keywords: universal jurisdiction - principle of subsidiarity - universal jurisdiction and international law - retroactivity and right to effective judicial protection.

\section{INTRODUCTION}

The approval of Ley Orgánica (Organic Act, hereinafter LO) I/20I4, ${ }^{\mathrm{I}}$ amending article 23 of Ley Orgánica del Poder Judicial (Organic Act of the Judicial Power, hereinafter LOPJ) has reopened once again in Spain the debate on universal jurisdiction. It is a debate that is not new, but this time it has given rise to a special controversy, both at the academic level and at the political and judicial levels.

However this debate is not exclusive of our country, it largely reflects a broader debate that has been developing for the two last decades at the international level, among governments, judges, lawyers, organizations defending human rights, governmental legal advisors, diplomats, politicians and, of course, academics. As a result of the importance given to the issue of universal jurisdiction, this topic has been addressed even by international organizations. One should underline, in this respect, the works developed in the framework of the consultations European Union-African Union, ${ }^{2}$

* Professor of International Law, Universidad Nacional de Educación a Distancia (UNED). Member and Special Rapporteur of the International Law Commission. E-mail: cescobar@der.uned.es. This paper has been elaborated as a part of the Research Project DER2013-45790-P: La protección de los valores de la comunidad internacional: inmunidad, justicia $e$ impunidad en el Derecho internacional contemporáneo (The protection of values of the international community: immunity, justice and impunity in contemporary International Law), financed by the Ministry of Economy and Competitiveness of Spain (MINECO).

See, Ley orgánica I/20I4, de I3 de marzo, de modificación de la Ley Orgánica 6/1985, de I de julio, del Poder Judicial, relativa a la justicia universal, at Boletín Oficial del Estado (BOE), 63, I4 March 20I4. Text available at $<$ www.boe.es/boe/dias/2014/03/14/pdfs/BOE-A-2014-2709.pdf>.

These consultations resulted in the constitution of an ad hoc group of experts, composed of European and African Jurists who submitted a technical report to both organizations. See AU-EU Expert Report on the Principle of Universal Jurisdiction, Council of the European Union, Doc. 8672/I/09/Rev.I, 16 April 2009. Text is available at $<$ register.consilium.europa.eu/doc/svv?l=ENG\&f=ST 86722009 REV I $>$ 
and - in particular- the process currently underway in the United Nations as a result of the inclusion on the agenda of the General Assembly in 2009 of the item "the scope and application of the principle of universal jurisdiction, ${ }^{3}$ the commission given to the Secretary-General to prepare a report on this issue based on the information received from States and relevant observers, ${ }^{4}$ and the constitution at the Sixth Committee of the General Assembly of a working group on this topic in 2010.5 In addition, attention must be drawn to the fact that the exercise of universal jurisdiction in any of its forms is at the origin of several cases submitted to international tribunals, including the International Court of Justice and the European Court of Human Rights. In this setting it is not surprising that scientific institutions of the importance of the Institut de Droit international ${ }^{6}$ and the International Law Association 7 are also dealing with this issue.

This debate has been fueled in recent decades by two new elements which have to be taken into account. On the one hand, the increase in the number of judicial proceedings set up in different countries against foreign political representatives or State officials on the basis of universal jurisdiction. On the other hand, the creation of international criminal tribunals, especially the International Criminal Court, that serves the same purpose as universal jurisdiction, namely: protecting values of the international community through the prosecution of international crimes. The first of these elements has led to an increase in conflicts in international relations and has been used as an argument to criticize the so-called politically-oriented approach to universal jurisdiction which, moreover, would run against another value of the international community such as the stability of international relations. The second element has been interpreted by critics of universal jurisdiction as proof that this form of extraterritorial state jurisdiction is no longer necessary today as it has been replaced by an international jurisdiction that can perform this function more effectively and without affecting stable and balanced international relations.

It is, in any case, a debate in which the parties have been stringing together their arguments in a dialectic exercise in which political and legal reasons have got mixed up, as well as different interpretations of principles and values of the international community such as sovereignty, the protection of human rights, inter-state relations stability or the fight against impunity. Accordingly, the debate on universal jurisdiction cannot be considered in any case as a minor debate referred exclusively to the mere distribution of judicial powers between states, but as an issue whose significance for international law and international relations goes far beyond. On the other hand,

GA Res. 64/117, I6 December 2009.

Ibid. The Secretary General reports have been published as UN. Docs. A/65/181, A/66/93, A/67/116, A/68/113 and A/69/174. Text available at <www.un.org/en/documents/ods/>.

GA Res. 65/33, 6 December 20I0, op. par. 2. See also GA Res. 66/103, 9 December 20II; 67/98, I4 December 20I2; 68/117, I6 December 2013 and 69/124, Io December 2014. Text available at <www.un.org/documents/resga.htm>.

6 See the Res. 2005/3, "Universal criminal jurisdiction with regard to the crime of genocide, crimes against humanity and war crimes", adopted at the Krakow Session. Text available at <www.idi-iil.org/idiE/resolutionsE/2005_Kra_03_en-pdf $>$. During the Session held in 2007 in Santiago de Chile, it was created a new Commission committed with the topic "Universal Jurisdiction in Civil Matters in Private International Law" whose work is currently underway.

See International Law Association, London Conference (2000), Committee on International Human Rights Law and Practice, Final Report on the exercise of Universal Jurisdiction in respect of gross Human Rights Offences. Text available at <http://www.ila-hg.org/download.cfm/docid/43F56C67-C59D-496E-A7C9FF418D88FCF4>. 
attention should be drawn to the fact that the international debate on universal jurisdiction is not being neither homogeneous nor linear, producing in practice an alternative, and even contradictory use of different arguments, especially by states, in order to defend their interests every time in a casuistic manner.

The debate on universal jurisdiction in Spain has not been oblivious to the international environment that has just been referred to. On the contrary, the treatment given in Spain to universal jurisdiction and its evolution reflects, to a great extent, debates, uncertainties and difficulties that universal jurisdiction is meeting at the international level.

\section{THE REFORM OF UNIVERSAL JURISDICTION IN SPAIN}

\section{(I) Universal jurisdiction and principle of subsidiarity: The reforms of 2002 and 2009}

As it is well known, the scope of universal jurisdiction in Spain has never been a peaceful matter. On the other hand, the possibility of establishing conditions for its exercise as well as the definition of its subsidiary character with respect to other foreign or international jurisdictions, have resulted in an interesting and changing case-law emanating both from the Audiencia Nacional (High Court) and the Tribunal Supremo (Supreme Court). In addition, the significance of the issue resulted in even the ruling of the Tribunal Constitucional (Constitutional Court, hereinafter TC), in its judgment 237/2005, of 26 September, issued in the Guatemala case, ${ }^{8}$ which concluded that universal jurisdiction has in Spanish Law a legal nature and not a constitutional one. Accordingly, the regulation of universal jurisdiction corresponds to the legislature, and judges cannot set requirements other than those legally established by lawmaking bodies'. As a result, the definition of the model of universal jurisdiction has to be understood as a manifestation of the legislative power. In doing so, the legislature makes a choice for legislative and judicial policy. ${ }^{\text {Io }}$ This universal jurisdiction setting left the way open for a possible amendment of article 23 of the LOPJ, in particular for the purposes of sorting out the main issues that were at the bottom of the case submitted to the TC, namely: (i) the establishment in our legal system of universal jurisdiction as a jurisdiction of last resort, through the incorporation of the principle of subsidiarity; and (ii) the possibility of introducing in Spanish law another requirements complementing subsidiarity as procedural conditions for the exercise of universal jurisdiction.

However, it must be noted that the judgment of the TC did not result immediately in a reform of the system for the purpose of incorporating, in particular, the subsidiary nature of universal

\footnotetext{
8 Text available at $<$ hj.tribunalconstitucional.es/HJ/es/Resolution/Show/5497>. See also TC Judgment (hereinafter STC) 227/2007, of 22 October. Text available at <hj.tribunalconstitucional.es/HJ/es/Resolution/Show/6194>.

See STC 237/2005, FJ 5 .

Such a declaration, however, did not prevent the TC from taking a stance, in that very judgment, on several requirements imposing conditions to the exercise of universal jurisdiction, and on the compatibility of those requirements with the concept and nature of universal jurisdiction considered in itself. In this regard, attention must be drawn to the statements concerning the meaning of the principle of subsidiarity (FJ 4), the national link and the national interest (FFJJ 6, 8 y 9), the victim's nationality (FJ 9) and the presence in the Spanish territory of the alleged perpetrator of the crime (FJ 7).
} 
jurisdiction. On the contrary, it must be recalled that, until 2009, amendments to article 23 of LOPJ were exclusively limited to introducing new crimes under the competence of Spanish tribunals for exercising universal jurisdiction. ${ }^{\text {II }}$ In fact, before that date, the only reform of universal jurisdiction serving the purpose of incorporating the principle of subsidiarity took place in 2003 on the occasion of the adoption of the Ley Orgánica de Cooperación con la Corte Penal Internacional (organic Act on cooperation with the International Criminal Court $)^{12}$, and such a reform was prior to the judgment of the TC, indeed. Pursuant to the provisions of article 7 (paras. 2 and 3 ) of the Act, the Spanish courts shall not exercise its jurisdiction -including universal jurisdiction - if the International Criminal Court has exercised or is about to exercise its jurisdiction over the same crimes, but it reserves in any case the possibility of exercising it later if the ICC finally does not exercise its preferential jurisdiction. It was, in any case, a very special course motivated by the need to establish a necessary balance between the maintenance of universal jurisdiction in Spain and the will not to unjustifiably prevent the exercise of its jurisdiction by the new International Criminal Court to the establishment of which Spain contributed actively. In any case, the above modifications of universal jurisdiction did not constitute an obstacle to the exercise of universal jurisdiction in Spain, as evidenced by the fact that the Audiencia Nacional opened in subsequent years new cases on the basis of this jurisdictional title.

Actually, only in 2009 was the first procedural reform of universal jurisdiction approved, through the Ley Orgánica (organic Act) I/2009 ${ }^{13}$ that, as pointed out in his Preamble, is adopted "[i]n compliance with the mandate emanating from the Chamber of Deputies [lower House of the Spanish Parliament], by resolution adopted on May 19, 2009 on the occasion of the Debate on the State of the nation", with the aim of "adapting and clarifying article 23.4 LOPJ, in accordance with the principle of subsidiarity and with the legal doctrine emanated from the Constitutional Court doctrine and the jurisprudence of the Supreme Court". Under this reform the principle of subsidiarity was defined as a general rule applicable to any case concerning universal jurisdiction, and the new requisite that the alleged perpetrator was located in Spain at the moment of exercising jurisdiction was added to the Spanish system of universal jurisdiction. If the first of the changes reflected the concept of universal jurisdiction as "jurisdiction of last resort", the second was the answer to serious practical problems arising during the exercise of universal jurisdiction as a result of the difficult and problematic application of the techniques of cooperation and international judicial assistance, in particular

II See Ley Orgánica 3/2005, of 8 July, amending Ley Orgánica 6/1985, of I July, for the prosecution of the practice of female genital mutilation extraterritorially (BOE, num. I63 $_{3}$, of 9 July 2005. Text available at <www.boe.es/boe/dias/2005/07/09/pdfs/A24457-24457.pdf>) and Ley Orgánica 13/2007, of 19 November, for the extraterritorial prosecution of illegal or clandestine immigration of persons (BOE, num. 278, of 20 November 2007. Text available at <www.boe.es/boe/dias/2007/II/20/pdfs/A47334-47335.pdf $>$ ). The list of offenses prosecutable by application of universal jurisdiction has been subsequently extended by LO I/2009 and LO I/20I4.

12 See Ley Orgánica 18/2003, of 1o December, on cooperation with the International Criminal Court (BOE, num. 296, of II December 2003. Text available at <www.boe.es/boe/dias/2003/r2/II/pdfs/A44062-44068.pdf >). Therefore, this reform was already in force at the time the TC issued its judgment in the case "Guatemala", despite its not making reference to it, probably by the fact that it is a unique case which is justified by the obligations assumed by Spain pursuant to the ratification of the Rome Statute.

I3 See Ley Orgánica I/2009, of 3 November (BOE, num. 266, of 4 November 2009. Text available at $<$ www.boe.es/boe/dias/2009/II/04/pdfs/BOE-A-2009-I7492.pdf >). 
extradition ${ }^{14}$. In any case, a major modification was determined by the incorporation of the principle of subsidiarity, whereby the Spanish courts had their jurisdiction limited when there is another competent jurisdiction, foreign or international, whose intervention would be preferred. .5 $^{\text {However, }}$ the new configuration of universal jurisdiction included three safeguard clauses allowing the Audiencia Nacional to continue with the exercise of universal jurisdiction in certain cases, even aside from the principle of subsidiarity, namely: (i) when an international treaty imposed the obligation for Spain to exercise universal jurisdiction; (ii) when courts whose jurisdiction was considered as preferential did not exercise their jurisdiction or were not able to exercise it; and (iii) when the case submitted to the Spanish courts presented a direct interest for Spain, either because the victim was Spanish, or because there exists — in a broader sense - "a relevant link to Spain" ${ }^{16}$.

In conclusion, both the 2003 and 2009 reforms kept universal jurisdiction as a jurisdictional title under Spanish Law. But on both occasions the legislature took into consideration the nature of universal jurisdiction as a "jurisdiction of last resort", which - for this reason - had to be adapted to the changes produced in national legislation and in international law with regard to the prosecution of the most serious crimes of international concern. In any case, it should be noted that although these two reforms of universal jurisdiction reduced its scope in our country, they did so without reducing the list of crimes to which it could be applied that; both reforms respected the international obligations assumed by Spain by virtue of international treaties; they took into consideration the jurisdictional link traditionally considered as preferred, namely, the territory in which the facts have taken place; and, finally, both reforms introduced no substantive or procedural requirements different from the principle of subsidiarity, with the only exception of the requirement that the alleged perpetrator was located in the national territory. On the other hand, the aforementioned reforms left intact the traditionally recognized margin of discretion to judges and courts to determine the extent of their own competence. A margin of discretion that the Audiencia Nacional exercised without hindrance in the years following such reforms. ${ }^{17}$

\section{(2) The reform of 2014, continuum or new model of universal jurisdiction?}

Against this background, the LO I/20I4 presents itself in its Preamble as a continuation of the reform of 2009, claiming to be construed on the basis of full respect of the rule of law and with the aim of strengthening legal certainty in relation to any exercise of universal jurisdiction; and stressing at the same time the conviction that "nowadays universal jurisdiction cannot be conceived but within the

\footnotetext{
I4 The great importance given to extradition in this setting was underlined at STC 237/2005, FJ 7.

The LO I/2009 refers exclusively to "another competent country" without expressly identifying which is the prevailing jurisdiction. However, on the basis of a systematic reading of the provisions of the LO, together with the references that the Act makes to the TC and TS jurisprudence, it could be deduced that the preferred jurisdictional link is the territory when the crime has been committed. Regarding the logic of the preferential nature of the territorial link, see STC 237/2005, FJ 4, third paragraph.

16 See LO I/2009, Art. I, par. one, new drafting of Art. 23.4 LOPJ.

17 The following cases can be cited: Couso (2003), Rwanda (2004), Tibet (2006 and 2008), CIA's Flights (2006), Sahara (2006), Atenco (sexist murders in México) (2008), Nazi concentration camps (2008), Gaza (2008), El Salvador (2008), Guantánamo (2009), Killing of Iranian Refugees in Ashraf (2009), Freedom Flotilla (2010), Carmelo Soria (2012).
} 
limits and requirements of international law" ${ }^{18}$ This new reform of universal jurisdiction raises important issues that cannot be addressed in its entirety in this commentary, given its necessary brevity. For this reason, in the following pages I will just make some critical comments on three issues which, in my opinion, are of special importance, namely: (i) the treatment given by LO I/20I4 to the principle of subsidiarity; (ii) the references to international law as the foundation of the reform; and (iii) the retroactive application of the new restrictive rules of universal jurisdiction.

\section{(a) The principle of subsidiarity in the reform of 2014}

Just as it happened with the reform of 2009, universal jurisdiction as an extraordinary last resort jurisdiction setting seems to be at the base of the 2014 reform. And, from this perspective, the principle of subsidiarity is intended to play a central role in it. However, despite the statement made in the first and second paragraphs of the Preamble of the LO I/20I4, the maintenance-of-the-statusquo character of the reform operated by that Act can be questioned. Especially if we consider that LO I/20I4 incorporates a series of radically new elements that differentiate it of the contents and the spirit that seem to have inspired the two reforms mentioned above, essentially based on the incorporation of the principle of subsidiarity. These contents include, in particular, the incorporation of the principle of double criminality as a requirement for exercising universal jurisdiction (new Article 23, 2 (a)); the requirement that there is a link between Spain and the author of the facts, either in the form of nationality, habitual residence or his physical presence in Spain (new Article 23, 2 and 4); or the link between the exercise of universal jurisdiction and the refusal to extradite an individual, with the consequent confusion between universal jurisdiction and the aut daedere aut judicare principle (new Article 23, 4, in fine). In addition, the reform included other modifications of general scope that are not related to the principle of subsidiarity, such as the amendment of the generally applicable rules of active legitimation in our legal system, which in this case is limited to the victims and to the public prosecutor's Office (new Article 23, 2 and 6). Or the establishment of a new and complex model of universal jurisdiction, whereby the scope of this jurisdiction varies depending on the crime to be prosecuted (new Article 23, 4), which breaks the model of uniform rules applicable prior to any form exercise of universal jurisdiction by Spanish courts.

It is true, however, that the new wording of article 23 of LOPJ still formally upholds the principle of subsidiarity that was defined in the reform of 2009, allowing the Spanish courts to exercise universal jurisdiction in those cases where international courts or competent foreigners tribunals were unable or unwilling to exercise their preferential jurisdiction (new Article 23, 5). However, this possibility is notably reduced in view of the application of the new elements that have been analyzed above, which - without any doubt - have already limited ab initio the scope of the jurisdiction. And, above all, the possibility of a subsidiary exercise of universal jurisdiction is greatly restricted for two basic reasons: (i) the requirement for a Spanish link to be always identified; and (ii) the limitation of the margin of technical appreciation which corresponds to the courts in the interpretation of the principle of subsidiarity. Regarding to the unavoidable need for a Spanish connection, it must be

\footnotetext{
I8 See LO I/20I4, Preamble, paragraphs fourth and second, respectively.
} 
stressed that it is questionable that this requirement was compatible with the concept of universal jurisdiction that, by definition and as a matter of law, implies the possibility of exercising jurisdiction apart from the national connection. To that, it must also be added a no less important criticism concerning the general strengthening of the Spanish connection which is subject to a contradictory treatment in the Act, as long as one of the most common national links usually applied in practice is partially excluded from this approach, namely: the universal jurisdiction of the Spanish courts in every case in which the victim is a Spanish national. With regard to the second element, attention must be drawn to the fact that the power for interpreting the principle of subsidiarity is attributed exclusively to the Supreme Court, which must circumscribe its case-law assessments to the interpretative criteria that are established in the Act which, in accordance with what is expressed therein, are only the interpretative criteria contained in the Rome Statute. In this regard, it should be noted that while it must be commended that lawmakers have taken into account rules contained in a treaty to which Spain is a party and that, therefore, binds our country, it would be desirable to consider whether these criteria are appropriate to be applied in a context other than the one for which they were defined in the Rome Statute. It must be added, finally, that the exclusive attribution of this interpretive competence to the Supreme Court cannot be understood but as a limitation for the Audiencia Nacional to rule on several aspects concerning its own competence.

In the light of what has just been said, it should be legitimately asked if the sole or main effect pursued by the reform of 2014 is to reinforce the principle of subsidiarity regarding international criminal courts (in particular the International Criminal Court) and foreign courts, and if the final regulation is consistent with the purpose stated in the Preamble. In the first case, the reform was unnecessary, since both the LO I/2009 and I8/2003 had already expressly regulated this manifestation of subsidiarity. In the second of the assumptions, it is undeniable that the strengthening of the application of the principle of subsidiarity in relation to foreign criminal courts may be conceived as one of the effects pursued by the reform of 2014, but it is debatable whether this was its main effect and purpose, especially if analyzed in the light of the new requirements introduced by the LO I/20I4 which, to a great extent, do not have any relationship with the subsidiary character of universal jurisdiction.

Accordingly, it should be questioned that the LO I/20I4 is a mere continuation of the reforms of 2003 and 2009. On the contrary, one may wonder if - as it has been profusely stated in various for athe reform pursues a different purpose, in particular to avoid any possible controversies that might arise in the context of international relations as a result of the exercise of universal jurisdiction. Even if this effect is actually the purpose of the reform, the new approach to universal jurisdiction is not necessarily in contradiction with the Spanish Constitution or International law. On the contrary, the legal -as opposed to constitutional- nature of universal jurisdiction in the Spanish legal system allows the legislative power to take into account this kind of arguments as a foundation in making a legitimate choice of legislative and judicial policy. Nevertheless, if it is the case, the reform should be evaluated from a different perspective and can be subjected to equally legitimate criticism, related to its accordance with political and ethical principles upon which our constitutional system is built, in particular the recognition of human rights and their protection as one of the basic pillars of the 
system and the need to establish mechanisms that allow for this pillar to be real and effective and not just a programmatic declaration. It is evident that this critical remark is of metajuridical nature, but that nature does not undermine its significance or be a reason for disdain. In particular if we assume that the reform of universal jurisdiction is a legislative choice to be made by the political power and, therefore, it can and should be assessed not exclusively in legal terms but from a metajuridical and policy approach.

\section{(b) Reform of universal jurisdiction and international law}

Secondly, it is also necessary to make some comments with regard to the reference made by the Act Preamble to International Law as the due reference or basis for the regulation of universal jurisdiction in Spain. In relation to this claim, it must be pointed out first that it is a laudatory aim which, moreover, is consistent with the importance that our country is attributing to international law as the inexcusable framework in which international relations must be developed. However, if we analyze in detail the content of the reform Act, we have to conclude with some criticisms concerning the concept of international law which underlies, as well as regarding the concept of universal jurisdiction which is reflected in the Act and its relationship with the concept and nature of that institution in contemporary international law.

With regard to the first of these issues, suffice it now to point out that LO I/20I4 is based on a reductionist conception of international law, which is identified with international treaties. Thus, despite the fact that the Preamble claims that the reform aims to adapt universal jurisdiction to existing international law, later the dispositive part of the Act is limited to adaptation of universal jurisdiction to treaties concluded by Spain and which may affect the exercise of the aforementioned jurisdiction. This reductionist approach does not seem, however, the most successful way to justify the reform from a technical perspective, since we cannot ignore the current broad international consensus on the existence of two types of universal jurisdiction that coexist peacefully, namely: (i) the universal jurisdiction which can be described as mandatory, since it is derived from international treaties; and (ii) the not compulsory, or optional, universal jurisdiction which can be freely established by States under their own sovereignty. Both forms of universal jurisdiction are in conformity with international law and, therefore, the option to maintain in our legal system only the compulsory universal jurisdiction constitutes a choice of legislative policy, in exercise of the sovereignty of the State, but cannot be interpreted as a mandatory reform needed in order to adapt our system to existing international law.

On the other hand, it could be also considered whether the new requirements laid down by the LO I/20I4 are fully compatible with the international treaties to which it refers. Although it is not possible to address this issue in detail in this brief paper, attention must be drawn at least to the problems that can be deduced from the existence of some requirements such as double criminality and the presence of a Spanish link, whether with the crime or with the alleged perpetrator of the crime. In this respect, suffice it to stress that in both cases those requirements can hardly be found in every treaty imposing or authorizing Spain to exercise of universal jurisdiction. 
Finally, in addiction to previous comments, a general remark has to be made concerning the referral by LO I/20I4 to the creation of the International Criminal Court as a basis or indirect cause of the reform. Indeed, the creation of the ICC has resulted in two complementary effects of remarkable importance for universal jurisdiction. Firstly, an international jurisdiction now exists which, in a general approach, can prosecute the most serious crimes of international concern. Secondly, the fact that as a result of the entry into force of the Rome Statute, a certain number of states have included in their national legislation the crimes defined in the Statute and, along with the crimes, jurisdiction for its own courts to prosecute them. On the basis of these elements, one should reflect on the impact that this international jurisdiction can or should have on the process of redefinition of the scope of universal jurisdiction as a jurisdiction of last resort. However, from such thoughts, it can hardly be deduced that universal jurisdiction has lost its raison d'être, or either that universal jurisdiction can be identified nowadays with a form of extraterritorial jurisdiction that only operates when there is an undisputed national link. On the other hand, attention must be drawn to the fact that the jurisdiction of the International Criminal Court is not universal and that, in any case, the exercise thereof is also subject to a number of technical limitations related - among other causes- to the cooperation of states with the Court. As a result, the parallelism between the existence of the International Criminal Court and the reduction to a minimum or even the disappearance of universal jurisdiction cannot be sustained in accordance with legal criteria. On the contrary, as an example of the positive relationship between universal jurisdiction and the International Criminal Court, suffice it to call attention to the fact that some States have introduced universal jurisdiction into their legal systems in the context of the process of domestic implementation of the Rome Statute. To this it must be added, on the other hand, the emergence in the framework of the works of the Assembly of States Parties of the ICC, of the so-called "positive complementarity", whose ultimate goal is to encourage the adoption by states of rules allowing their national courts to exercise jurisdiction over the crimes included in the Rome Statute, even under the form of universal jurisdiction.

\section{(c) Universal jurisdiction and retroactivity}

To conclude these brief reflections on the reform operated by the LO I/20I4, it is necessary to address the rule of retroactivity contained therein, which constitutes one of the most weak and controversial points of the reform. According to this rule, "the cases dealing with crimes included in this reform which, at the time of the entry into force of this Act, are undergoing proceedings shall be stayed until it is ascertained that the requirements established by this Act are met". ${ }^{19}$ This rule is justified in the Preamble by the argument that "Spanish courts cannot continue proceedings over which they no longer have jurisdiction”. It is, without any doubt, an ingenious and effective mechanism to achieve the goal of halting immediately any judicial action that could be underway at the time of entry into force of the law and, therefore, eliminate any possible differences that may have arisen or might subsequently arise within the framework of the international relations of Spain. From this perspective,

\footnotetext{
19 LO I/2014, "Transitory Clause" (Disposición transitoria única).
} 
the retroactivity seems to be an important feature of the choice of legislative and judicial policy reflected in $\mathrm{LO} \mathrm{I} / 20 \mathrm{I} 4$.

However, the aforementioned approach cannot be considered as the only valid reference for evaluating the retroactivity rule. On the contrary, it is necessary to reflect on this rule from a different perspective, namely: its compatibility with the international and constitutional principles that govern the right to a fair trial, including the right to have access to the courts and, more broadly, the right to effective judicial protection. This analysis should start with the finding that the implementation of the mandate contained in the LO I/20I4 has resulted in the filing of a procedure which, when initiated, was in accordance to the law and from which some rights and legal expectations have been generated for the complainant and for the victims. In this context, the filing of proceedings without transitional periods or alternative courses of action means a loss of the right to an effective judicial protection even when the proceedings had already been validly initiated at the relevant procedural date. From this point of view, such an effect is hardly compatible with the international and constitutional principles that define the right to a fair trial, including access to tribunals. In particular, this is clear if we take into account the fact that the filing of the proceedings, with the consequent irrevocable loss of the right to effective judicial protection, is neither based on a lack of object of the claim nor on any procedural reason attributable to the complainants, but on the retroactive application of a restrictive rule, jurisdictional in nature, affecting fundamental rights.

\section{SOME FINAL CONSIDERATIONS}

After three decades since it was established in the Spanish judicial system, universal jurisdiction remains an institution that is as needed as it is controversial. Beginning with the second component of this pairing, it is undeniable that the exercise of universal jurisdiction is facing real difficulties in the procedural order, essentially by means of the limitations of international cooperation and judicial assistance and their deficient application in a certain number of cases. Another difficulty lies in the fact, that cannot be ignored, that the exercise of universal jurisdiction has inevitable and unintended consequences on international relations and that, therefore, can affect negatively some other interests of the state. Despite this, universal jurisdiction remains a necessary institution, inasmuch as it constitutes the last resort available to victims and to the international community in general to achieve a judicial response to international crimes that, it should not be forgotten, constitute violations of the essential values of the international community. From this perspective, a state whose legal system is based on the respect for the rule of law and human rights and that, furthermore, declares itself to be committed to the respect of international law and the values it defends, can hardly forgo this jurisdictional title in its judicial system. Therefore, the key lies in striking an appropriate and fair balance between both elements, which is essential for the survival and correct functioning of universal jurisdiction. Achieving this balance has never been easy, as it has been demonstrated throughout the process of reform of universal jurisdiction in Spain. Despite this, the maintenance of universal jurisdiction has remained a hallmark of the Spanish judicial system since the arrival of 
democracy to our country, regardless of the fact that it has been resized by the necessary implementation of the principle of subsidiarity.

Contrary to this approach, the 2014 reform has taken a quantum leap with respect to previous reforms, in particular by introducing changes that significantly affect the very concept and nature of universal jurisdiction, and by setting it within so narrow a margin that the risk of disfiguring the institution is real and it may be extremely difficult, if not impossible, its exercise by the Spanish courts. In these circumstances, one could legitimately wonder if we are facing a new limitative reform of universal jurisdiction or actually facing a tacit abrogation of universal jurisdiction in the Spanish judicial system. And, no less important, the 20I4 reform obliges us to reflect about the limits that the public powers have no right to trespass when choosing between one and another formulation of universal jurisdiction.

There is no doubt that these questions will continue to give rise to an intense debate in the coming years. But, aside from this, the Copernican turnaround of universal jurisdiction produced by the application of the $\mathrm{LO}_{\mathrm{I}} / 2 \mathrm{OI} 4$ should force us to a serious and serene reflection about the consequences that this reform will generate, not only in terms of the management of concrete interests in the immediate present, but also from a wider perspective in which other type of considerations must be included, among which neither the axiological approach nor the consequences linked to the image of Spain at international level can be absent. 